\title{
Bhakti Marga: \\ Jalan Menuju Tuhan Melalui Cinta Kasih
}

Puspo Renan Joyo

\begin{abstract}
Abstrak
Tulisan ini adalah studi tentang metode pendekatan diri kepada Tuhan melalui Bhakti. Di dalam agama Hindu, upaya mendekatkan diri kepada Tuhan dapat ditempuh melalui pelbagai cara atau metode. Setidaknya dikenal empat cara yang secara populer diketahui sebagai Catur Marga. Keempat itu adalah, Bhakti jalan bhakti, Jnana, Karma dan Raja. Jalan Bhakti merupakan metode pemujaan Tuhan bagi orang-orang yang bertemperamen bhakti. Ini adalah jalan yang terbatas pada Tuhan dan mereka yang mencari penyatuan melalui cinta kasih. Jalan ini merupakan kasing sayang yang mendalam kepada Tuhan, yang merupakan jalan kepatuhan atau pengabdian.

Bhakti merupakan satu pengetahuan spiritual terpenting Mereka yang mencintai Tuhan tak memiliki keinginan ataupun kesedihan. Ia tak pernah membenci makhluk atau benda apapun, dan tak pernah tertarik dengan objek-objek duniawi. Ia merangkul semuanya kedalam dekapan hangat kasing sayangnya. Kama (keinginan duniawi) dan trsna (kesenangan/kemelekatan terhadap duniawi) merupakan musuh dari rasa bhakti. Selama ada jejak-jejak keinginan dalam pikiran terhadap objek duniawi, kita tak pernah memiliki kerinduan yang mendalam terhadap Tuhan.
\end{abstract}

Kata Kunci : Bhakti Marga, Saguna Brahman-Nirguna Brahman, Nawawidha-Bhaki.

\begin{abstract}
This paper is the study of the method of approaching oneself to God through Bhakti. In Hinduism, efforts to get closer to God can be pursued through various methods. there are four ways popularly known as Catur Marga. The four are, bhakti, jnana, karma and raja. Bhakti is a method of worshiping God for a person of bhakti character or service sincerely and lovingly. This is the way for those who seek union through love. This path is a deep affection for God, which is the path of obedience or devotion.

Bhakti is the most important spiritual knowledge for those who love God and have no desire or sadness. He never hates any creature or object, never interested in worldly objects. He loves all beings. Kama (worldly desires) and trsna (pleasure or attachment to the world) are enemies of bhakti. As long as there is a desire in the mind of a worldly object, we never have a deep desire for God.
\end{abstract}

Keywords: Bhakti Marga, Saguna Brahman-Nirguna Brahman Nawawidha-Bhaki 


\section{PENDAHULUAN}

Cogito Ergo Sum "aku berpikir maka aku ada", demikian ungkapan termasyur yang diutarakan oleh Rene Descartes, seorang filsuf ternama dari Perancis, penemu filsafat modern dan bapak matematika modern. Ungkapan tersebut menyiratkan tentang relasi eksistensi pikiran dan manusia. Ketiadaan pikiran dalam dirimu manusia, dengan demikian menyirnakan makna keberadaannya. Eksistensi akal atau pikiran dalam dirimu manusia itulah yang oleh banyak pihak dinyatakan sebagai kelebihan manusia dibanding makhluk lain di bumi ini. Bahkan tanpa akal pikirannya manusia tak berbeda dengan binatang, demikian Aritoteles.

Harold H. Titus secara lebih spesifik menyatakan "Man is an animal organism, it is true but he is able to study himself as organism and to compare and interpret living forms and to inquire about the meaning of human existence". Selanjutnya Harold menyebutkan beberapa faktor yang berkaitan dan menjadi karakteristik manusia sebagai pribadi, yaitu: 1) Self conscioueness (kesadaran diri); 2) Reflective thinking, abstract thought, or the power of generalization, (berpikir reflektif, pemikiran abstrak, atau kekuatan generalisasi); 3) Ethical discrimination and the power of choice (diskriminasi etik dan kekuatan dalam menentukan pilihan); 4) Aesthetic appreciation (penghargaan terhadap nilai-nilai keindahan); 5) Worship and faith in a higher power (sikap bhakti dan keyakinannya terhadap kekuatan yang lebih tinggi); 6) Creativity of a new orde. Dalam kesusastraan Hindu, dibanding dengan makhluk lain khas manusia itu terletak pada kepemilikan idep (akal, pikiran, wiweka atau kemampuan analitik). Karenanya ia dikatakan utama sebagai ciptaan. Berangkat dari kepemilikan akal atau pikirannya itu, manusia juga disebut homo sapien, yakni makhluk yang berpikir. Berangkat dari keberadaan akal atau pikirannya, manusia lalu berkembang dan berkebudayaan (homo humanus), menciptakan alat-alat kebudayaan (homo faber), berbicara (homo languens), hidup bermasyarakat (homo socius), mengerti akan keindahan (homo aesteticus), dan menyadari adanya kekuatan gaib yang memiliki kemampuan lebih hebat daripada kemampuan manusia, sehingga menjadikan manusia berkepercayaan atau beragama (homo religius).

Penjelasan mengenai keutamaan manusia dapat dijumpai dalam Sarasamuccaya 2 dan 4, sebagai berikut: (2) Ri sakwehning sarwa bhuta, iking janma wwang juga wenang gumawayaken ikang subhasubhakarma, kuneng panentasakena ring subhakarma juga ikangasubhakarma 
phalaning dadi wwang (Manusia adalah satu-satunya mahluk yang dapat melakukan kebajikan pun kejahatan. Terlahir menjadi manusia bertujuan untuk melebur perbuatan-perbuatan jahat ke dalam perbuatan-perbuatan bajik, hingga tidak ada lagi perbuatanperbuatan jahat yang masih tersisa dalam diri, inilah hakekat menjadi manusia. Hanya dengan menjadi manusia kejahatan itu dapat dilebur dalam kebajikan); (4) Apan iking dadi wwang, uttama juga ya, nimittaning mangkana, wenang ya tumulung awaknya sangkeng sangsara, makasadhanang subhakarma, hinganing kottamaning dadi wwang ika (Menjadi manusia adalah kelahiran yang paling utama. Karena hanya dengan menjadi manusia sajalah kebajikan/kebenaran dapat dilakukan, dan hanya dari kebajikan/kebenaran itulah kesengsaraan dapat dibenahi) (Kajeng, 1999:4-6).

Manusia sebagai Homo Religious berarti ia membutuhkan kelengkapan rohaniah untuk menenangkan jiwanya yang cenderung tidak pernah puas dengan tuntutan kebutuhan materi setiap harinya. Manusia perlu mengisi jiwanya dengan makanan rohani yang ia peroleh dari agama atau kepercayaan yang ia peluk. Dengan demikian, sambil terus berusaha, ia selalu berupaya untuk mengantungkan hidupnya pada kehendak yang kuasa. Jalaludin (2011:53) menyatakan, hampir seluruh ahli jiwa sependapat bahwa sesungguhnya apa yang menjadi keinginan dan kebutuhan manusia itu bukan hanya terbatas pada kebutuhan makan, minum, pakaian ataupun kenikmatan-kenikmatan lainnya. Berdasarkan hasil riset dan observasi, mereka mengambil kesimpulan bahwa pada diri manusia terdapar semacam keinginan dan kebutuhan-kebutuhan lainnya, bahkan mengatasi kebutuhan akan kekuasaan. Keinginan akan kebutuhan tersebut merupakan kebutuhan kodrati, berupa keinginan untuk mencintai dan dicintai Tuhan.

Kehadiran Tuhan menjadi kebutuhan pokok dalam kehidupan batin manusia. Bagi umat Hindu, Tuhan tidak saja menjadi sumber tuntunan dan sandaran tetapi juga tujuan. Karenanya, obsesi tertinggi manusia Hindu adalah kembali menuju kepadaNya. Uniknya, Hindu tidak saja memberikan hanya jalan yang tunggal untuk dapat merealisasikan setiap individu untuk menginsyafi Tuhan, tetapi memberikan pilihan jalan sebagaimana yang dijelaskan dalam Veda, yang sesuai dengan karakteristik masing-masing. Salah satu jalan yang dimaksud adalah jalan mendekatkan diri kepada Tuhan melalui cinta kasih atau Bhakti Marga. Tulisan ini dimaksudkan untuk mengkaji mengenai Bhakti Marga 
secara secara sederhana.

\section{Pembahasan}

\subsection{Bhakti dalam Konstelasi Catur}

\section{Marga dan Karakteristiknya}

Ye yatha mam prapadyantetams

tathaiva bhajamy aham, mama vartmanuvartante manusyah partha sarvasah

Terjemahan :

Wahai Arjuna, sejauh mana orangorang menyerahkan dirinya kepadaKu, sejauh itu pula Aku memberikan berkah kepada mereka semua. Memang, dalam segala hal umat manusia mengikuti jalanKu (Darmayasa, 2015:49).

Sloka Bhagawadgita IV.11 ini merupakan pandangan universal dari ajaran Hindu tentang ajaran bhakti atau jalan pemujaan terhadap Tuhan. Tuhan menanggapi setiap penyembahnya dengan bebas dan memberkahinya sesuai dengan keinginan hati masingmasing. Tuhan tidak akan memupus harapan siapapun tetapi membantu semua harapan agar dapat tumbuh sesuai dengan kodratnya masing-masing.

Nama dan wujud dipergunakan untuk mencapai yang tanpa wujud, sehingga wujud apapun yang disukai dapat dipakai. Para pemikir Hindu menyadari bahwa pelbagai macam jalan dapat ditempuh dalam usaha untuk mendekati Tuhan; karena tak mungkin bagi siapapun juga untuk dapat memberikan gambaran dari Realitas Tertinggi itu. Srimad Bhagawadgita VII. 3 \& 26 menjelaskan (Darmayasa, 2015:83,89):
Manusyanam sahasresu Kascid yatati siddhaye,

Yatatam api siddhanam Kascin mam vetti tattvatah

Terjemahan:

Diantara ribuan orang, barangkali ada satu orang yang berusaha mencari kesempurnaan hidup. Dan diantara mereka yang sudah mencari kesempurnaan hidup, barangkali hanya satu orang yang bisa mengetahui kebenaran sejati tentang diriKu.

\section{Vedaham samatitani Vartamanani carjuna,}

Bhavisya ca bhutani Mam tu veda na kascana

Terjemahan:

Wahai Arjuna, Aku mengetahui makhluk-makhluk hidup yang pernah ada pada masa lalu, yang sedang ada pada masa kini, dan juga yang akan ada pada masa yang akan datang. Tetapi, (selain pemujaKu yang murni) tidak satupun ada yang mengetahui diriKu.

Secara metafisik (paramartha), tak ada manifestasi apapun yang dapat dipakai sebagai kenyataan mutlak, sementara dari sudut pandang pengalaman (wyawahara), masingmasing wujud yang dipilih memiliki validitas tertentu; dan wujud-wujud yang kita puja membantu kita untuk menyadari keberadaan sang diri batin kita. Selama objek pemujaan itu tertanam kuat, ia akan merasuki pikiran dan batin serta bersemayam disana (Waswinara, 2008:226 
Bhakti Marga merupakan satu dari empat jalan dalam rangka merealisasikan Tuhan, selain Karma Marga, Jnana Marga dan Raja Marga. Bhakti Marga merupakan metode pemujaan Tuhan bagi orang-orang yang bertemperamen bhakti. Ini adalah jalan yang terbatas pada Tuhan dan mereka yang mencari penyatuan melalui cinta kasih. Jalan ini merupakan kasing sayang yang mendalam kepada Tuhan, yang merupakan jalan kepatuhan atau bhakti dan disenangi oleh sebagian besar umat manusia. Mengasihi demi untuk kasih sayang itu sendiri adalah motto dari bhakti marga. Tuhan adalah pengejawantahan dari kasih sayang, dan setiap insan akan dapat mencapai-Nya dengan mencintai-Nya. Tuhan dapat diwujudkan melalui cinta kasih seperti cinta suami istri yang menggelora dan menyerap segalanya. cinta kasih kepada Tuhan harus senantiasa diusahakan. Mereka yang mencintai Tuhan tak memiliki keinginan ataupun kesedihan. Ia tak pernah membenci makhluk atau benda apapun, dan tak pernah tertarik dengan objek-objek duniawi. Ia merangkul semuanya kedalam dekapan hangat kasing sayangnya. Kama (keinginan duniawi) dan trsna (kesenangan/kemelekatan duniawi) merupakan musuh dari rasa bhakti. Selama ada jejak-jejak keinginan dalam pikiran terhadap objek duniawi, kita tak pernah memiliki kerinduan yang mendalam terhadap Tuhan (Sivananda, 2003:133-135). Bhagawad Gita II. 59 dan II.71 (Darmayasa, 2015:28,31) menjelaskan:

Visaya vinivartante Niraharasya dehinah,

Rasa-varjam raso'py asya Param drstva nivartate

Terjemahan:

Mereka yang sudah menjauhkan indria-indrianya dari obyek-obyek indria barangkali obyek indriaindria terjauhkan tetapi rasa kepuasan indria masih tetap ada. Akan tetapi dengan mengalami rasa kepuasan yang maha tinggi di dalam Tuhan Yang Maha Esa, maka rasa kepuasan duniawi menjadi tidak ada.

Vihaya kaman yah sarvan Pumams carati nihsprhah,

Nirmamo nirahankarah Sa santim adhigacchati

Terjemahan:

Orang yang sudah meninggalkan segala jenis keinginan hawa nafsu, hidup bebas dari keinginan, bebas dari rasa kepemilikan, bebas dari keakuan palsu, (orang seperti itu) mencapai kedamaian yang sejati.

\section{Atma-Niwedana merupakan} penyerahan diri secara total setulus hati kepada Tuhan, yang merupakan anak tangga tertinggi dari Nawawidha Bhakti (sembilan cara bhakti). Atma-Niwedana adalah prapatti atau Saranagati. Si penyembah menjadi satu dengan Tuhan melalui Prapatti dan memperoleh karunia Tuhan atau Prasada. Cinta kasih 
Tuhan dan kegairahan yang menggelora yang dinikmati karena persekutuan dengan Tuhan tak dapat digambarkan secara tepat dengan kata-kata. Hanya orang bisu yang telah mencicipi enaknya makanan yang tidak dapat mengatakan tentang hal itu. Ia hanya dapat diperlihatkan kepada beberapa orang yang terpilih saja. Hanya mereka yang telah mengalami cinta kasih itu akan dapat melihat, mendengar dan membicaraknya, karena ia terus menerus berpikir tentangnya. Bhakti merupakan suatu ilmu spiritual terpenting, karena mereka yang memiliki rasa cinta kasih kepada Tuhan, sesungguhnya kaya. Tak ada kesedihan selain tidak memiliki rasa bhakti kepada Tuhan. Tak ada tujuan yang benar kecuali kasih sayang dari penyembah kepada Tuhan. Nama, sifat dan lila Tuhan merupakan objek meditasi yang harus diingat. Kaki padma Tuhan merupakan objek meditasi terpenting. Para penyembahnya meminum madu prema atau cinta kasih Tuhan. Tak ada perbedaan golongan sosial, keyakinan, keluarga, warna kulit, ras diantara penyembah, karena Tuhan tidak memandang pada hal-hal seperti itu. Tuhan melihat kemurnian hati para penyembah, sehingga siapapun dapat menjadi seorang penyembah Tuhan. Nanda, yang tak tersentuh; Rai Das, seorang penyamun; Kannappa, seorang pemburu; Sena, seorang tukang cukur;
Kabir, seorang penenun Islam, dan Sabari, seorang Bhilini. Kesemuanya penyembah Tuhan dan merupakan orang-orang suci yang agung. Kannappa, seorang barbar yang kurang pendidikan yang memuntahkan air dari mulutnya ke atas Lingga dan mempersembahkan daging babi hutan, menjadi bhakta terbaik. Para Alwar Waisnawa dan Nayanar Saiwa dari India Selatan, berasal dari golongan masyarakat yang berbeda-beda (Sivananda, 2003:135-136).

\subsection{Saguna Brahman dan Nirguna Brahman}

Bila kita mengkaji tentang Brahman (Tuhan Yang Maha Esa) di dalam kitab suci Veda, maka kita menemukan dua ke-Tuhan-an, yaitu Tuhan sebagai yang berwujud (Saguna Brahman) dan yang tidak berwujud (Nirguna Brahman). Hal ini sebagaimana dijabarkan dalam Bhagavadgita pada bab XII yang berjudul Bhakti Yoga sloka 1-4, ketika Arjuna bertanya kepada Sri Krishna mana yang lebih sempurna, orang yang selalu tekun dalam bhakti (Saguna Brahman) ataukah orang yang menyembah Tuhan yang tidak bersifat pribadi dan tidak berwujud (Nirguna Brahman). Dalam penjabarannnya Sri Krishna menjawab bahwa pada dasarnya keduanya akan mencapai kepadaNya, namun praktik Nirguna 
Brahman lebih sulit dilakukan bagi manusia yang memiliki badan ini. praktih Bhakti (Saguna Brahman) dipandang paling sempurna bagi manusia. Demikian penjelasanya sloka tersebut (Prabhupada, 2006:609-614) :

Arjuna uvāca evam satata-yuktā ye bhaktās tvām paryupāsate ye cāpy akșaram avyaktam tesām ke yogavittamāh

Terjemahan:

(Arjuna bertanya: Yang mana dianggap lebih sempurna: orang yang selalu tekun dalam bhakti kepada Anda dengan cara yang benar ataukah orang yang menyembah Brahman, yang tidak bersifat pribadi dan tidak terwujud?).

śrī-bhagavān uvāca mayy āveśya mano ye mām nitya-yuktā upāsate śraddhayā parayopetās te me yuktatamā matāh

Terjemahan :

(Kepribadian Tuhan Yang Maha Esa bersabda: Orang yang memusatkan pikirannya pada bentuk pribadi-Ku dan selalu tekun menyembah-Ku dengan keyakinan besar yang rohani dan melampaui hal-hal duniawi Aku anggap paling sempurna).

ye tv aksaram anirdeśyam avyaktam paryupāsate

sarvatra-gam acintyam ca küta-stham acalam dhruvam

sanniyamyendriya-grāmam sarvatra sama-buddhayah

te prāpnuvanti mām eva sarva-bhūtahite ratāh
Terjemahan :

Tetapi orang yang sepenuhnya menyembah yang tidak terwujud, di luar jangkauan indera-indera, yang berada di mana-mana, tidak dapat dipahami, tidak pernah berubah, mantap dan tidak dapat dipindahkan-paham tentang Kebenaran Mutlak yang tidak mengakui bentuk pribadi Tuhandengan mengendalikan inderaindera, bersikap yang sama terhadap semua orang, dan sibuk demi kesejahteraan semua orang, akhirnya mencapai kepada-Ku).

kleśo 'dhikatar as tesām avyaktāsaktacetasām avyaktā hi gatir duhkham dehavadbhir avāpyate

Terjemahan :

(Orang yang pikirannya terikat pada aspek Yang Mahakuasa yang tidak berwujud dan tidak bersifat pribadi sulit sekali maju. Kemajuan dalam disiplin itu selalu sulit sekali bagi orang yang mempunyai badan).

Sivananda (2003:9-10) menyatakan bahwa Hinduisme sangatlah universal, bebas, toleran dan luwes. Inilah gambaran indah tentang Hinduisme. Seorang asing merasa terpesona keheranan apabila ia mendengar tentang sekta-sekta dan keyakinan yang berbeda-beda dalam Hinduisme; tetapi perbedaan-perbedaan itu sesungguhnya merupakan berbagai tipe pemikiran dan temperamen, sehingga menjadi bermacam-macam keyakinan pula. Hal ini adalah wajar. Hal ini merupakan ajaran yang utama 
dari Hinduisme; karena dalam Hinduisme tersedia tempat bagi semua tipe roh dari yang tertinggi sampai yang terendah, demi untuk pertumbuhan mereka.

Pernyataan ini jelas merangkum semua kemampuan umat-Nya untuk membayangkan Tuhan Yang Maha Esa. Bagi mereka yang tinggi pengetahuan rohaninya, Tuhan Yang Maha Esa digambarkan dalam pikirannya sebagai Impersonal God (tanpa Wujud baik dalam pikiran maupun dalam kata-kata) sedang bagi yang pemahamannya sederhana, Tuhan Yang Maha Esa digambarkan sebagai Personal God, berpribadi dan dibayangkan sebagai wujud-wujud yang agung, maha kasih, maha besar, dan sebagainya. Pada umumnya umat beragama menyembah Tuhan Yang Maha Esa yang personal ini. Penggambaran dalam alam pikiran manusia umumnya sebagai yang serba mulia, suci, luhur agung dan tinggi, jauh di alam sana.

Dari penghayatan Tuhan sebagai yang personal inilah kemudian memunculkan pola-pola pendekatan dalam cara bhakti atau semua bentuk penghayatannya personal God ini terakomodasi dalam bentuk Bhakti . Jalan ini disebut sebagai jalan yang paling mudah, sederhana dan tidak memerlukan biaya yang banyak, dan hampir seluruh umat Hindu menempuh jalan bhakti ini. Dari ajaran bhakti inilah muncul pengarcaan (membuat arca, sebagai saran memuja keagungan-Nya, membuat bangunan suci yang indah dan sebaginya)

\section{.2.3. Ajaran Bhakti dalam Veda}

Pokok-pokok ajaran bhakti dapat kita jumpai dalam kitab suci Veda, menunjukkan bahwa sejak Veda diturunkan dan diterima oleh para maha rsi mengembangkan unsur bhakti dalam dirinya. Berikut ini adalah kutipan beberapa mantra-mantra Veda yang mengajarkan Bhakti, sebagai berikut:

Om bhur bhuvah svah Tat savitur varenyam

Bhargo devasya dhimahi Dhiyo yo nah pracodayat

Terjemahan:

Ya Tuhan Yang Maha Esa, Sumber segala yang ada, luhur dan maha mulia, pencipta alam semesta. Kami memuja kemahamuliaan$\mathrm{Mu}$, anugerahkanlah kecerdasan dan budi pekerti yang luhur kepada kami (Yajurveda XXXVI.3).

Bhadram karnebhih srnuyama deva Bhadram pasyemaksabhir yajatrah Sthirair angais tustuvamsas tanubhir Vyasema hi devahitam yad ayuh

Terjemahan:

Ya Tuhan Yang Maha Esa, anugerahkanlah kepada kami untuk mendengar hal-hal yang baik dan ya Tuhan Yang Maha Suci, kami dapat melihat hal-hal yang baik dan semogalah kami dapat memersembahkan bhakti 
kami dengan kekuatan tangan dan keteguhan badan kami, dapat menikmati kebahagiaan sejati sesuai dengan hukum kemahakuasaan-Mu (Rgveda I.89.9, Yajurveda XXV.21).

\section{Purusa evedam sarvam Yad bhutam yacca bhavyam}

Utamrtatvasyesa no yad Annenati rohati

Terjemahan:

Tuhan Yang Maha Esa adalah asal dari segala yang ada dan yang kan ada. Ia adalah raja dan penguasa alam yang kekal abadi dan dunia fana ini tempat tumbuhnya makanan (tanaman) (Rgveda X.90.2).

Isa vasyam idam sarvam Yat kim ca jagatyam jagat

Tena tyaktena bhunjitha Ma grdhah kasya svid dhanam

Terjemahan:

Hendaknya dipahami bahwa segalanya diresapi oleh Tuhan Yang Maha Esa, segala yang bergerak dan yang tidak bergerak di alam semesta. Hendaknya orang tidak terikat dengan berbagai kenikmatan dan tidak rakus serta menginginkan milik orang lain (Yajurveda XI.1).

Agnim manye pitaram agnim apim Agnim bhrataram sadami tsakhayam, Agner anikam brhatah saparyam Divi sukram yajatam suryasya

Terjemahan

Tuhan Yang Maha Esa yang kami yakini sebagai bapak kami, sanak kerabat dan saudara kami, kami puja Engkau sebagai yang memiliki wajah yang agung, sinar suci Surya di langit (Rgveda X.7.3).

Tvam eva mata ca pita tvam eva Tvam eva bandhus ca sakha tvam eva, Tvam eva vidya dravinam tvam eva Tvam eva sarvam mama deva-deva

Terjemahan:

Tuhan Yang Maha Esa sesungguhnya adalah ibu kami, bapak kami, sahabat kami dan keluarga kami. Tuhan Yang Maha Esa sesungguhnya pemberi pengetahuan dan Engkau penganugerah kekayaan. Engkau adalah segalanya, ya Engkau adalah dewata tertinggi daari seluruh dewata (Guru Stotra 14).

Dari beberapa mantram Veda yang mengajarkan bhakti ini, Maharsi Naradha dalam kitabnya Naradha Bhakti Sutra (I.2) merumuskan bahwa bhakti itu sesungguhnya parama prema atau parama premarupa, cinta kasih sejati, yang tertinggi. Kasih yang sejati digambarkan sebagai kasih dari seorang bapak, sanak saudara, sahabat dan di dalam Gurupuja, Tuhan Yang Maha Esa tidak saja digambarkan sebagai seorang ibu dan bapak, tetapi juga sebagai keluarga dan sahabat, pemberi pengetahuan dan kekayaan. berdasarkan penjelasan tersebut, maka pengertian bhakti seperti nampaknya dekat dengan yajna, yakni pengorbanan yang tulus dengan landasan kesucian hati dan berseminya kasih sayang. Selanjutnya dalam kitab Sabdakalpadruma III.463b, 
kata bhakti dinyatakan sebagai Vibhaga (pembagian atau pemisahan, memisahkan penyembah dan yang disembah), Seva (pemujaan atau pelayanan). Selanjutnya para ahli Sanskerta, menyatakan bahwa kata bhakti berasal dari akar kata bhaj yang berarti memuja, cinta kasih yang sejati kepada-Nya dengan penuh perasaan dan ketulusan. Di dalam Brahma Sutra atau Vedanta Sutra, pengertian tentang bhakti diungkapkan diungkapkan dalam kalimat sutra sebagai berikut : athatobhaktijijnasa, sekarang diuraikan makna bhakti, saparanuraktisvare, cinta kasih yang sejati kepada Tuhan Yang Maha Esa dari seseorang dengan sepenuh hati. Jadi pengertian tentang bhakti ini sejalan dengan makna kata parama prema kasih yang tinggi dan sejati (Titib, 2003).

Dalam Bhagawad Gita (Waswinara, 2008:16-17) kita jumpai penjelasan tentang empat orang yang berusaha mendekati diri, berbhakti kepada Tuhan Yang Maha Esa, yakni :

Catur-vidha bhajante mam Janah sukrtino 'rjuna,

Arto jijnasur artharthi Jnani ca bharatasabha

Terjemahan:

The virtous ones who worship Me are of four kinds, the man in distress, the seeker for knowledge, the seeker for wealth and the man of wisdom, O Lord of the Bharatas (Arjuna).

\section{Tesam jnani nitya-yukta Eka-bhaktir visisyate,}

Priyo hi jnanino 'tyartham Aham sa ca mama priyah

Terjemahan:

Of these the wise one, who is ever in constant union with the Divine, whose devotion single-minded, is the best. For I am supremely dear to him and he is dear to Me.

Keempat jenis orang yang berusaha mendekati Tuhan dapat dikategorikan dalam empat (4) jenis menurut Bhagawad Gita, yaitu orang yang sengsara, yang mengejar pengetahuan, yang mengejar kekayaan, dan yang terakhir adalah orang yang bijaksana/berbudi luhur. Diantara keempat macam orang tersebut, dinyatakan bahwa orang yang berbudhi luhur/bijaksana dikatakan sebagai yang paling mulia. Mengapa demikian, karena orang yang berbudhi luhur sepenuhnya menyerahkan diri kepadaNya. Penyerahan diri secara total ini disebut prapatti, demikianlah bhaktiprapatti mengandung makna bhakti yang murni, sebab mereka telah merasakan dalam kebhaktiannya itu, ia berada dalam lindungan-Nya. Bila kita bhakti dan menyerahkan diri sepenuh hati, maka Tuhan Yang Maha Esa hadir di hadapan kita, menganugerahkan sesuatu yang menjadi harapan kita dan melindungi yang kita miliki.

Ananyas cintayanto Mam ye janah paryupasate, 
Tesam nityabhiyuktanam Yoga-ksemam vahamy aham

Terjemahan

But those who worship Me, medidating on $\mathrm{Me}$ alone, to them who ever perserve, I Bring attainment of what they have not and security in what they have (Waswinara, 2008:322).

Ada dua jenis atau bentuk bhakti, yaitu para bhakti dan apara bhakti. Para bhakti mempunyai makna yang sama dengan prapatti, yakni penyerahan diri secara total kepada-Nya sedang apara bhakti adalah bhakti dengan pelbagai permohonan dan permohonan yang diangap wajar, misalnya keselamatan atau memohon berkembang-mekarnya budhi nurani, sedangkan permohonan untuk kekayaan dan kekuasaan, sering disebut bhakti yang bersifat rajas dan tamas. Perlu ditegaskan bahwa prapatti itu bukan fatalistik, artinya dengan penyerahan diri kepada-Nya, kemudian yang bersangkutan tidak bekerja sebagaimana tidak melakukan tugas dan kewajiban dengan baik. Tuhan Yang Maha esa di dalam kitab suci Veda tegas menyatakan bahwa Dia hanya menyayangi umat manusia yang suka bekerja keras dan tidak malas.

\subsection{Nawawidha Bhakti}

Nawawidha Bhakti atau Navalaksana Bhakti adalah sembilan cara bhakti atau bentuk bhakti yang terjabarkan dalam kitab Bhagavata Purana VII.5.23, sebagai berikut :

Sravanam kirtanam visnoh smaranam pada sevanam

Arcanam vandanam dasyam sakhyam atma nivedanam

Terjemahan:

Sembilan bentuk bhakti kepada Sang Hyang Visnu, yaitu (1). Sravanam, (2). Kirtanam, (3). Smaranam, (4). Pada Sevanam, (5). Arcanam, (6). Vandanam, (7) Dasyam, (8). Sakhyam, (9). Atma Nivedanam (Titib, 2003:55)

Adapun penjelasan dari sloka di atas yaitu :

1. Sravanam, yaitu mempelajari keagungan Tuhan Yang maha Esa melalui membaca atau mendengarkan pembacaan kitabkitab suci.

2. Kirtanam, mengucapkan/ menyanyikan nama-nama Tuhan Yang Maha Esa.

3. Smaranam, mengingat nama Tuhan atau meditasi tentang-Nya.

4. Padasevanam, memberikan pelayanan kepada Tuhan Yang Maha Esa, termasuk melayani, menolong pelbagai makhluk ciptaan-Nya

5. Arcanam, memuja keagunganNya umumnya dengan sarana arca 
dan persembahan air, bunga, bijibijian, buah-buaha, dan sebagainya.

6. Vandanam, sujud bhakti kepada Tuhan Yang Maha Esa.

7. Dasya, melayani-Nya dengan pengertian mau melayani mereka yang memerlukan pertolongan dengan penuh keikhlasan, memandang mereka sebagai ciptaan-Nya.

8. Sakhya, memandang Tuhan Yang Maha Esa sebagai sahabat sejati, yang memeberikan pertolongan ketika dalam bahaya.

9. Atmanivedanam, penyerahan diri secara total kepada-Nya.

Nawawidha Bhakti atau Navalaksana Bhakti menjabarkan mengenai varian bhakti dalam Hindu. sekaligus memberikan paradigma baru bahwa bhakti tidak hanya duduk bersila dipura (sembahyang), bhakti tidak hanya berisi ritualistik konvensional seperti yang selama ini kita lihat dan laksanakan dalam praktek keagamaan sehari-hari melainkan bhakti memiliki makna yang sangat luas dan dalam. Bhakti tidak semata-mata bermakna vertikal, dan individualisme namun juga vertikal dan sosial. Belajar mengenai bhakti berarti juga berfilsafat mengenai pemujaan, pelayanan dan bagaimana kita berbuat yang terbaik untuk semua makhluk hidup.

Hal ini dapat kita cermati satu demi satu dari penjelasaan mengenai Nawawidha Bhakti atau Navalaksana Bhakti di atas. Misalnya mengenai Dasya. Dasya adalah melayani Tuhan. Dalam pelayanan kepada Tuhan tidak semata-mata hanya berupa pelayanan $\mathrm{d} \mathrm{a} 1 \mathrm{am}$ a k t i vitas d a $1 \mathrm{am}$ pemujaan/persembahyangan saja. Pelayanan kepada Tuhan dapat juga kita lakukan dengan jalan membantu dan menolong kepada sesama makhluk, sebagai ciptaan Tuhan, dan sebagainya. Sehingga, bhakti (Nawawidha Bhakti) selain mendidik diri untuk tulus dan taat berserah diri kepada-Nya juga mengajarkan kita untuk bagaimana menumbuh-kembangkan rasa cinta kasih, simpati dan empati kepada sesama ciptaan Beliau.

Bentuk atau contoh perwujudan bhakti di atas dapat dilihat dari pelbagai cerita, baik dalam kitab-kitab Itihasa seperti Ramayana dan Mahabharata maupun kitab-kitab Purana. Untuk memantapkan pemahaman kita tentang bhakti ini, kami kutipkan dua cerita (Titib, 2003:56-61), yaitu cerita tentang kebhaktian Hanuman kepada Sri Rama dalam ramayana dan cerita mengenai Arjuna Pramada sebagai berikut :

\section{Bhakti Hanoman Kepada Sri Rama}

Saat itu, setelah penobatan Vibhisana sebagai maharaja dan kota Lengka sudah diganti namanya menjadi Srilanka, semua pasukan Sri Rama telah 
kembali ke Ayodhya. Sri Rama bersama dewi Sita dan laksmana mengendarai kereta terbang bernama Manipuspaka yang merupakan hadiah dari dewa Kuvera. Setibanya di keraton Ayodhya segera dilaksanakan upacara Abhivandana, yaitu upacara syukuran atas kejayaan Sri Rama berhasil menundukkan Ravana. Pada persidangan agung yang mulia dihadiri oleh seluruh petinggi kerajaan, Sri Rama membagi-bagikan berbagai hadiah kepada siapa saja yang pernah berjasa dalam memenangkan perang untuk merebut kembali dewi Sita. Setelah setiap pejabat tinggi mendapat hadiah, selanjutnya dipanggillah Hanuman untuk menerima hadiah dari Sri Rama. Saat itu Hanuman tampil berdatang sembah, dengan sangat hormat ia menyatakan tidak bersedia lagi menerima hadiah. Alasan Hanuman, dengan Sri Rama mengijinkan dirinya sebagai abdi sang Purna Avatara, dirinya sudah mendapatkan hadiah yang tiada taranya, sebab siapa saja yang dekat dengan Tuhan Yang Maha Esa, para dewa atau avatara-Nya, seseorang menikmati kebahagiaan yang sejati.

Terhadap penolakan Hanuman ini, Sri Rama dan dewi Sita kembali mendesak Hanuman untuk bersedia menerima hadiah sebagai kenang-kenangan at as keberhasilan di medan perang. Demikian pula keberhasilan Hanuman sebagai duta serta keberanian dan kekuatan Hanuman menadapat pujian dari segenap yang hadir. Hanuman tidak menjawab. Saat itu dewi Sita berbisik kepada suaminya, untuk mengijinkan kalung mutiara hadiah Prabu Janaka, ayahanda dewi Sita diberikan kepada Hanuman. Sri Ramapun menyetujuinya, walaupun kalung mutiara itu memiliki arti yang istimewa bagi Sri Rama dan dewi Sita, karena dihadiahkan saat Sri Rama berhasil mematahkan busur milik dewa Siwa dalam sayembara dan berhasil $\mathrm{m}$ e $\mathrm{m}$ e $\mathrm{n}$ a $\mathrm{ngk}$ a $\mathrm{n}$ s e r t a mempersunting dewi Sita sebagai istrinya. Saat hanuman tertunduk, Sri Rama langsung membuka kalung Dewi Sita dan $\mathrm{t}$ a m p i l k d e p a menyerahkannya kepada Hanuman. Hanuman seperti terpaksa menerima hadiah itu. Hanuman merasa malu, seorang yang telah lama diterima sebagai abdi harus menerima hadiah, bukankah hal ini salah satu wujud kerakusan? Setelah Hanuman menerima hadiah tersebut, satu-persatu butiran mutiara itu diperhatikan oleh Hanuman, maksudnya untuk menemukan gambar Sri Rama dan Sita pada biji-biji mutiara tersebut. Ia pun tidak menemka hal itu, tanpa disadari ia menggeleng-gele ngkan kepalanya dan kemudian menggigit rangkaian mutiara itu dan melemparkannya ke tanah. Hadirin tercengang dan gemas menyaksikan kejadian itu. Panglima Sugriva langsung marah dan membentak Hanuman. "Hai Hanuman, engkau kera hina tidak tahu diri, kelakuanmu itu memalukan, kuhancurkan wajahmu! Kau 
telah hina persidangan yang agung ini. Ia berdiri tegak sambil mengepalkan tangan hendak memukul Hanuman. Bila saja tidak di depan persidangan yang mulia itu, Sugriva pasti sudah menempeleng muka Hanuman. Sugriva sangat geram, tubuhnya gemetar menahan marah.

$\mathrm{Pad}$ a s a t y a n $\mathrm{g}$ menegangkan itu, Sri Rama dan Sita tersenyum dan memandang Sugriva yang sedang marah. Demikian tatapan Sri Rama dan Sita menyapu wajah Sugriva, saat itu pula emosi dan kemarahan Sugriva lenyap. Sri Rama dan dewi Sita benar-benar mengalirkan pancaran kasih yang tiada taranya. Selanjutnya Sri Rama mendatangi Hanuman dan menepuk bahunya : “ Engkau seperti anak kecil, mengapa lakukan hal itu?". Maaf tuan Sri Rama dan ibu dewi Sita, hamba telah mengecewakan persidangan yang mulia ini. Memang hamba seekor kera yang hina, tetapi hamba kira diri hamba tidak lebih rendah dari seorang manusia. Bagi hamba dengan diijinkan sebagai abdi, hamba sudah bahagia, karena ketika hamba dekat dengan tuan dan ibu sebagai perwujudan Avatara Tuhan Yang Maha Esa dan Dewi Laksmi, saat itu pula kebahagiaan tiada taranya hamba peroleh dari tuan. Bukankah dengan pemberian hadiah ini hamba menunjukkan kerakusan hamba?".

Sri Rama kembali menepuk bahu Hanuman. "tidak! Engkau tidak rakus. Lalu apa yang engkau minta Hanuman? Katakanlah, jangan seperti anak kecil !". "Baiklah tuan dan ibu dewi Sita, bila hamba boleh meminta lagi, ijinkanlah hamba senantiasa dekat tidak saja secara jasmaniah tetapi tuan dan ibu dewi Sita hendaknya selalu berada di hati kami. Untuk itu sudikah tuan Sri Rama dan ibu dewi Sita untuk berstana pada jantung hati kami. Pada singgasana bunga hati kami. Bila tuan dan ibu dewi Sita berkenan bersthana, maka itulah hadiah yang senantiasa hamba mohon".

Sri Rama selanjutnya berdiri tegak dan bersabda : "hai Hanuman dan hadirin yang tercinta dan supaya di dengar pula oleh seluruh jagat raya. Siapa saja yang maju selangkah menghadap aku dan mau mendekatkan dirinya serta membuka pintu hatinya. Aku akan datang sepuluh langkah mendekati mereka, masuk ke dalam hatinya dan memberikan kebahagiaan yang sejati tiada taranya!. Mendengar sabda Sri Rama demikian merdu dan menggetarkan alam semesta. Hanuman dengan mencium kaki Sri Rama terlebih dahulu, kemudian menegakkan dadanya. Dengan kekuatan "bayubajra", bagaikan kekuatan petir, tibatiba dengan kukunya dengan kukunya yang tajam ia menoreh dadanya. Dan dengan tenaga yang dahsyat, tiba-tiba ia merobek dadanya, darah berhamburan keberbagai arah. Saat itu pula Sri Rama dan dewi Sita hilang dari singgasana kencananya yang indah. Suasana menjadi hening dan terdengar mantra-mantra para dewa dan rsi-rsi surga dengan taburan bunga harum semerbak, 
nampaklah cahaya gemerlapan pada dada Hanuman yang menganga lebar. Pada cahaya itu kemudian nampak sebuah singgasana emas di atas padma hati Hanuman. Ketika itu Kelihatan Sri Rama dan dewi Sita duduk melambaikan tangan dengan sikap abhaya dan varamudra, yaitu sikap tangan menjauhkan serta menolak bencana dan memebri hadiah. Hadirin mengucapkan jaya-jaya Sri Rama, jaya-jaya dewi Sita. Setelah suasana hening kembali. Hanumanpun menutup dadanya, tidak nampak ada luka dan tibatiba Sri Rama dan dewi Sita sudah kembali bersthana pada singgasana kencana di depan persidangan.

Demikian cerita singkat dari kisah Ramayana yang memberikan pendidikan secara simbolis, bila dihati kita telah bersthana sang Avatara, para dewa manifestasi Tuhan Yang Maha Esa, maka niscaya kebahagiaan akan selalu berada dalam diri kita. Berbagai upacara termasuk piodalan/pujawali dan lainlain mengandung makna untuk mendekatkan diri, maka Tuhan Yang Maha Esa dalam wujud-Nya sebagai Anandarupa, yakni kebahagiaan yang sejati akan turun dan memberikan kebahagiaan yang tak terhingga kepada kita.

Demikianlah cerita tentang bhakti yang sejati adalah sesungguhnya pelayanan kepada-Nya, lebih jauh kami petikkan tentang arogansinya Arjuna yang populer dengan dikenal dengan cerita Arjuna Pramada, mengisahkan perjumpaan Arjuna dengan Hanuman, Arjuna merasakan betapa kelirunya bila tidak hormat dan bhakti kepada AvataraNya.

\section{Simpulan}

Berdasarkan analisis paparan yang disajikan tersebut, dapat disimpulkan sebagai berikut:

Pertama, nilai kebhinekaan sistem kosmologi Hindu Kaharingan dalam pengobatan tradisioal suku DHK, terdapat dua elemen dasar yakni kosmologi lisan dan tulisan yang memiliki kesejajaran pandangan dengan inti ajaran pengobatan Hindu terhadap konsep sehat sakit. Kondisi sehat (barigas) tercapai apabila kondisi fisik, psikis, dan mental dalam keadaan seimbang. Sebaliknya, keadaan sakit (haban) terjadi apabila kondisi fisik, psikis, dan mental mengalami ketidakseimbangan. Kondisi sehat sakit (barigas haban) diyakini oleh masyarakat suku DHK terjadi karena faktor alam, manusia, dan roh-roh atau merupakan faktor naturalistik dan personalistik.

Kedua, selain sistem keyakinan terhadap sehat sakit (barigas haban), pada aspek yang lebih luas yaitu suku DHK memiliki bentuk perawatan penyakit yang tampak cukup beragam akan tetapi mengerucut pada dua tindakan yaitu pengobatan tradisional 
dan pengobatan beomedis (rumah sakit). Dalam pengobatan tradisional meliputi pengobatan melalui tabit-tabit (dukun). Pengobatan tradisional tersebut erat kaitannya dengan persepsi orang suku DHK terhadap etiologi penyakit yang bersifat personalistik.

\section{Daftar Pustaka}

Foster, 1986. Antropologi Kesehatan. Universitas Indonesia. Koentjaraningrat, 1987, Sejarah Teori Antropologi I dan II. Jakarta Unipersitas Indonesia Press.

Sosial dalam Pembangunan Kesehatan. Jakarta,

Kumbara, 2004. Fungsi dan Makna Ritual Melukat dalam Penyembuhan Gangguan Jiwa di Bali.

Kumbara, 2013. Bali Puseh, Sistem Pengobatan Usada Bali.

Nala, 2003. Jurnal Ilmu Agama Dan Kebudayaan, Ayur Weda Sebagai Ilmu Kedokteran, Denpasar, Program Pasca.

Riwut Nila, 2003. Menyelami Kekayaan Leluhur. Yogyakarta : Pusakalima.

Suka Yasa, 2003. Jurnal Ilmu Agama Dan Kebudayaan, Mitos AsalUsu 1 A yurveda D a n Diturunkannya Kepada Umat Manusia, Program Pasca.

Sukiada, Kadek. 2016 "Sistem Medis Tradisional Suku Dayak dalam $\mathrm{K}$ e perc a y a n $\mathrm{Hind} \mathrm{u}$ Kaharingan di Kota Palangka Raya, Provinsi Kalimantan Tengah", Disertasi, Ilmu Agama Dan Kebudayaan UNHI Denpasar. 
Dharma Duta

Jurnal Penerangan Agama Hindu Vol. 16 No. 1, 2018 